\title{
Synthesis and characterization of $\eta^{5}$-cyclopentadienyl-silylallyl niobium and tantalum complexes
}

\author{
Pilar Nicolás, Pascual Royo * \\ Departamento de Química Inorgánica, Facultad de Ciencias, Universidad de Alcalá, Campus Universitario, \\ E-28871 Alcalá de Henares, Spain \\ Received 16 July 2004; accepted 6 September 2004 \\ Available online 21 November 2004
}

Dedicated to Professor F.G.A. Stone in recognition of his outstanding contribution to organometallic chemistry

\begin{abstract}
Reaction of the disilylcyclopentadiene 1,1-[SiMe $\left.2\left(\mathrm{CH}_{2} \mathrm{CH}=\mathrm{CH}_{2}\right)\right]_{2} \mathrm{C}_{5} \mathrm{H}_{4}$ with $\mathrm{NbCl}_{5}$ gave the new allylsilyl-substituted monocyclopentadienyl niobium complex $\left[\mathrm{Nb}\left\{\eta^{5}-\mathrm{C}_{5} \mathrm{H}_{4} \mathrm{SiMe}_{2}\left(\mathrm{CH}_{2} \mathrm{CH}=\mathrm{CH}_{2}\right)\right\} \mathrm{Cl}_{4}\right]$. This compound was reacted with $\mathrm{LiNH} t \mathrm{Bu}$ or $\mathrm{NH}{ }_{2} t \mathrm{Bu}$ to give the imido derivative $\left[\mathrm{Nb}\left\{\eta^{5}-\mathrm{C}_{5} \mathrm{H}_{4} \mathrm{SiMe}_{2}\left(\mathrm{CH}_{2} \mathrm{CH}=\mathrm{CH}_{2}\right)\right\}(\mathrm{N} t \mathrm{Bu}) \mathrm{Cl}_{2}\right]$, which was further alkylated to the imido alkyl complexes $\left[\mathrm{Nb}\left\{\eta^{5}-\mathrm{C}_{5} \mathrm{H}_{4} \mathrm{SiMe}_{2}\left(\mathrm{CH}_{2} \mathrm{CH}=\mathrm{CH}_{2}\right)\right\}(\mathrm{N} t \mathrm{Bu}) \mathrm{R}_{2}\right] \quad\left(\mathrm{R}=\mathrm{Me}, \mathrm{CH}_{2} \mathrm{Ph}\right)$ and $\left[\mathrm{Nb}\left\{\eta^{5}-\mathrm{C}_{5} \mathrm{H}_{4} \mathrm{SiMe}_{2}\left(\mathrm{CH}{ }_{2} \mathrm{CH}=\mathrm{CH}_{2}\right)\right\}(\mathrm{N} t \mathrm{Bu}) \mathrm{Cl}\right.$ $\left.\left(\mathrm{CH}_{2} \mathrm{Ph}\right)\right]$. Reaction of the imido complexes with the corresponding lithium cyclopentadienides gave the dicyclopentadienyl-imido complexes $\left[\mathrm{M}\left(\eta^{5}-\mathrm{C}_{5} \mathrm{R}_{5}\right)\left\{\eta^{5}-\mathrm{C}_{5} \mathrm{H}_{4} \mathrm{SiMe}_{2}\left(\mathrm{CH}_{2} \mathrm{CH}=\mathrm{CH}_{2}\right)\right\}(\mathrm{N} t \mathrm{Bu}) \mathrm{Cl}\right](\mathrm{M}=\mathrm{Nb}, \mathrm{Ta} ; \mathrm{R}=\mathrm{H}, \mathrm{Me})$. Metallocene dichlorides [M $\left(\eta^{5}\right.$ $\left.\left.\mathrm{C}_{5} \mathrm{R}_{5}\right)\left\{\eta^{5}-\mathrm{C}_{5} \mathrm{H}_{4} \mathrm{SiMe}_{2}\left(\mathrm{CH}_{2} \mathrm{CH}=\mathrm{CH}_{2}\right)\right\} \mathrm{Cl}_{2}\right](\mathrm{M}=\mathrm{Nb}$, Ta; $\mathrm{R}=\mathrm{H}, \mathrm{Me})$ were easily prepared by reduction with $\mathrm{Na} / \mathrm{Hg}$ and simultaneous transmetallation of $\left[\mathrm{Ta}\left(\eta^{5}-\mathrm{C}_{5} \mathrm{R}_{5}\right) \mathrm{Cl}_{4}\right]$ with $\mathrm{Li}\left[\mathrm{C}_{5} \mathrm{H}_{4} \mathrm{SiMe}_{2}\left(\mathrm{CH}_{2} \mathrm{CH}=\mathrm{CH}_{2}\right)\right]$ and of $\left.\left[\mathrm{Nb}_{2} \eta^{5}-\mathrm{C}_{5} \mathrm{H}_{4} \mathrm{SiMe}_{2}\left(\mathrm{CH}_{2} \mathrm{CH}=\mathrm{CH}_{2}\right)\right\} \mathrm{Cl}_{4}\right]$ with $\mathrm{Li}\left(\mathrm{C}_{5} \mathrm{R}_{5}\right)$. All of the new compounds have been characterized by elemental analysis, and IR and NMR spectroscopy.
\end{abstract}

(C) 2004 Elsevier B.V. All rights reserved.

Keywords: Niobium; Tantalum; Imido; Cyclopentadienyl

\section{Introduction}

Important efforts have been made to elucidate the behavior of the alkene-alkyl cationic species responsible for the catalytic activity of group 4 metallocene complexes in Ziegler-Natta type polymerization of $\alpha$-olefins [1]. With this aim, we synthesized olefin-tethered group 4 metallocene complexes [2] containing the allylsilylcyclopentadienyl ligand and studied the coordination of its olefinic moiety. The metal-olefin interaction in these $\mathrm{d}^{0}$ metal compounds is essentially due to the weak $\sigma$ donation from the olefin $\pi$-bonding MO to the cationic metal center strengthened by a significant electrostatic

\footnotetext{
* Corresponding author. Tel.: +34918854765; fax +34 918854683.

E-mail address: pascual.royo@uah.es (P. Royo).
}

contribution from the polarized olefinic system. These results encouraged us to prepare similar group 5 metal derivatives, which would allow comparison of the nature of the metal-olefin interaction of the related $\mathrm{d}^{0}$ and $\mathrm{d}^{2}$ metal complexes. The weakly coordinating properties reported [3] for the dicyclopentadienyl $\left[\mathrm{MCp}_{2} \mathrm{R}_{2}\right]^{+}$cations, which are stabilized by strong $\alpha$-agostic interactions [4], recommended the isolobal analogs [5-8], cyclopentadienyl imido compounds (a), as better models for $\mathrm{d}^{0}$, whereas the neutral dicyclopentadienyl metal(III) (b) derivatives were the most suitable models for $\mathrm{d}^{2}$ species, as shown in Scheme 1. The results of these studies have been reported [9] separately.

Both (a)- and (b)-type complexes may be easily accessible from the half-sandwich niobium and tantalum complexes $\left[\mathrm{M}\left\{\eta^{5}-\mathrm{C}_{5} \mathrm{H}_{4} \mathrm{SiMe}_{2}\left(\mathrm{CH}_{2} \mathrm{CH}=\mathrm{CH}_{2}\right)\right\} \mathrm{Cl}_{4}\right]$ through 


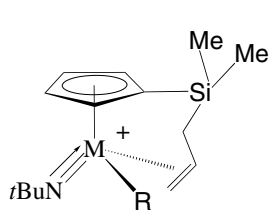

(a)

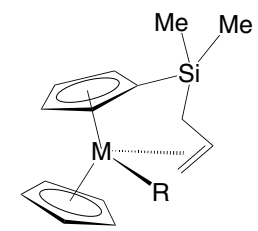

(b)
Scheme 1.

conversion into the imido derivatives $\left[\mathrm{M}\left\{\eta^{5}-\mathrm{C}_{5} \mathrm{H}_{4}\right.\right.$ $\left.\left.\mathrm{SiMe}_{2}\left(\mathrm{CH}_{2} \mathrm{CH}=\mathrm{CH}_{2}\right)\right\} \mathrm{Cl}_{2}(\mathrm{~N} t \mathrm{Bu})\right]$ and into the dicyclopentadienyl metal(IV) compounds $\left[\mathrm{M}\left(\eta^{5}\right.\right.$ $\left.\left.\mathrm{C}_{5} \mathrm{H}_{5}\right)\left\{\eta^{5}-\mathrm{C}_{5} \mathrm{H}_{4} \mathrm{SiMe}_{2}\left(\mathrm{CH}_{2} \mathrm{CH}=\mathrm{CH}_{2}\right)\right\} \mathrm{Cl}_{2}\right]$, followed by further reduction by alkylation and reductive elimination of alkane. Here, we report the synthesis and structural characterization of these precursor chloro complexes and their alkylated derivatives.

\section{Results and discussion}

\subsection{Synthetic results}

Desilylation of silylcyclopentadienes by reaction with electrophilic metal halides is a convenient method [10] to prepare silylcyclopentadienyl niobium [11], tantalum [12] and group 6 metal [13] complexes. The selectivity of this reaction, when two different silyl groups are bound to the ring, is not only dependent on the nature of the silyl substituents but also on the metal halide.

The reaction of $\mathrm{NbCl}_{5}$ with $\left[1-\mathrm{SiMe}_{2}\left(\mathrm{CH}_{2} \mathrm{CH}=\right.\right.$ $\left.\left.\mathrm{CH}_{2}\right)\right]\left(1-\mathrm{SiMe}_{3}\right) \mathrm{C}_{5} \mathrm{H}_{4}$ ] [2] gave a mixture containing a $1 / 1$ molar ratio of the already reported $\left[\mathrm{Nb}\left(\eta^{5}-\mathrm{C}_{5} \mathrm{H}_{4} \mathrm{Si}\right.\right.$ $\left.\left.\mathrm{Me}_{3}\right) \mathrm{Cl}_{4}\right]$ [14] and $\left[\mathrm{Nb}\left\{\eta^{5}-\mathrm{C}_{5} \mathrm{H}_{4} \mathrm{SiMe}_{2}\left(\mathrm{CH}_{2} \mathrm{CH}=\mathrm{CH}_{2}\right)\right\}-\right.$ $\left.\mathrm{Cl}_{4}\right] 1$ regardless of the solvent or the reaction conditions used. Compound 1 could be separated by repeated recrystallization from toluene but always in low yield $(<30 \%)$ and containing small amounts of the other component. The same reaction with $\mathrm{TaCl}_{5}$ took place with selective elimination of $\mathrm{SiClMe}_{2}\left(\mathrm{CH}_{2} \mathrm{CH}=\mathrm{CH}_{2}\right)$ affording pure $\left[\mathrm{Ta}\left(\eta^{5}-\mathrm{C}_{5} \mathrm{H}_{4} \mathrm{SiMe}_{3}\right) \mathrm{Cl}_{4}\right]$ [15]. For this reason, we decided to use the symmetric disilylated cyclopentadiene 1,1-[ $\left.\mathrm{SiMe}_{2}\left(\mathrm{CH}_{2} \mathrm{CH}=\mathrm{CH}_{2}\right)\right]_{2} \mathrm{C}_{5} \mathrm{H}_{4}$ [9]. As shown in Scheme 2, this compound reacted easily with $\mathrm{NbCl}_{5}$ to give the desired monocyclopentadienyl derivative $\mathbf{1}$ in

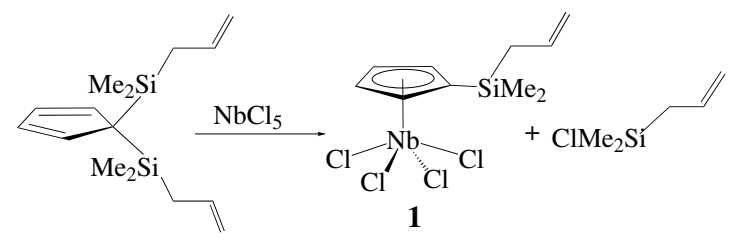

Scheme 2.
$80 \%$ yield as a red solid identified by analytical data and NMR spectroscopy. However, the same reaction using $\mathrm{TaCl}_{5}$ was not successful and the related tantalum derivative could not be isolated.

Transformation of monocyclopentadienyl metal(V) compounds into metallocene dichlorides was achieved by reaction with the corresponding lithium cyclopentadienides in the presence of 1 equiv of $\mathrm{Na} / \mathrm{Hg}$ in toluene (see Scheme 3). In this way, reaction of 1 with $\mathrm{Li}\left(\mathrm{C}_{5} \mathrm{H}_{5}\right)$ afforded $\left[\mathrm{Nb}\left(\eta^{5}-\mathrm{C}_{5} \mathrm{H}_{5}\right)\left\{\eta^{5}-\mathrm{C}_{5} \mathrm{H}_{4} \mathrm{SiMe}_{2}\left(\mathrm{CH}_{2} \mathrm{CH}=\mathrm{CH}_{2}\right)\right\}\right.$ $\left.\mathrm{Cl}_{2}\right] 2$ and similar reactions of $\left[\mathrm{Ta}\left(\eta^{5}-\mathrm{C}_{5} \mathrm{R}_{5}\right) \mathrm{Cl}_{4}\right]$ $\left(\mathrm{R}=\mathrm{H}\right.$ [16], Me [17]) with $\mathrm{Li}_{5} \mathrm{C}_{5} \mathrm{H}_{4} \mathrm{SiMe}_{2}\left(\mathrm{CH}_{2} \mathrm{CH}=\right.$ $\left.\mathrm{CH}_{2}\right)$ ] gave the related tantalum compounds $\left[\mathrm{Ta}\left(\eta^{5}\right.\right.$ $\left.\left.\mathrm{C}_{5} \mathrm{R}_{5}\right)\left\{\eta^{5}-\mathrm{C}_{5} \mathrm{H}_{4} \mathrm{SiMe}_{2}\left(\mathrm{CH}_{2} \mathrm{CH}=\mathrm{CH}_{2}\right)\right\} \mathrm{Cl}_{2}\right] \quad(\mathrm{R}=\mathrm{H} \quad$ 3, Me 4). The paramagnetic compounds $2-4$ were isolated in $60-70 \%$ yields as brown $(\mathbf{2}, \mathbf{3})$ and green $(\mathbf{4})$ air sensitive solids which can be stored indefinitely under inert atmosphere. The compounds, which were very soluble in toluene and THF, and partially soluble in hexanes, were identified by elemental analysis.

Reaction of complex 1 with 1 equiv of $\mathrm{LiNH} t \mathrm{Bu}$ in the presence of 1 equiv of $\mathrm{NEt}_{3}$ takes place with elimination of the lithium and ammonium salts to give the imido complex $\left[\mathrm{Nb}\left\{\eta^{5}-\mathrm{C}_{5} \mathrm{H}_{4} \mathrm{SiMe}_{2}\left(\mathrm{CH}_{2} \mathrm{CH}=\mathrm{CH}_{2}\right)\right\}\right.$ $\left.(\mathrm{N} t \mathrm{Bu}) \mathrm{Cl}_{2}\right] \mathbf{5}$ in $70 \%$ yield (see Scheme 4). The same transformation can also be carried out using 3 equiv of $\mathrm{NH}_{2} t \mathrm{Bu}$ or 1 equiv of $\mathrm{NH}_{2} t \mathrm{Bu}$ and 2 equiv of $\mathrm{NEt}_{3}$, although the resulting yields were lower. Complex 5 was isolated as a yellow solid after cooling its concentrated hexane solution at $-30{ }^{\circ} \mathrm{C}$ and was identified by elemental analysis and NMR spectroscopy.

Alkylation of complex 5 with 2 equiv of $\mathrm{MgClR}$ $\left(\mathrm{R}=\mathrm{Me}, \mathrm{CH}_{2} \mathrm{Ph}\right)$ resulted in substitution of both chloro ligands to give the corresponding dialkyl derivatives $\left[\mathrm{Nb}\left\{\eta^{5}-\mathrm{C}_{5} \mathrm{H}_{4} \mathrm{SiMe}_{2}\left(\mathrm{CH}_{2} \mathrm{CH}=\mathrm{CH}_{2}\right)\right\}(\mathrm{N} t \mathrm{Bu}) \mathrm{R}_{2}\right] \quad(\mathrm{R}=$ Me 6, $\mathrm{CH}_{2} \mathrm{Ph} 7$ ) in $70 \%$ and $80 \%$ yield, respectively, whereas the same reactions using 1 equiv of the alkylating agent gave unresolvable mixtures of mono- and di-alkyl compounds in different molar ratios. However the mono-benzyl complex $\left[\mathrm{Nb}\left\{\eta^{5}-\mathrm{C}_{5} \mathrm{H}_{4} \mathrm{SiMe}_{2}\left(\mathrm{CH}_{2}\right.\right.\right.$ $\left.\left.\left.\mathrm{CH}=\mathrm{CH}_{2}\right)\right\}(\mathrm{N} t \mathrm{Bu}) \mathrm{Cl}\left(\mathrm{CH}_{2} \mathrm{Ph}\right)\right] \mathbf{8}$ could be isolated as a

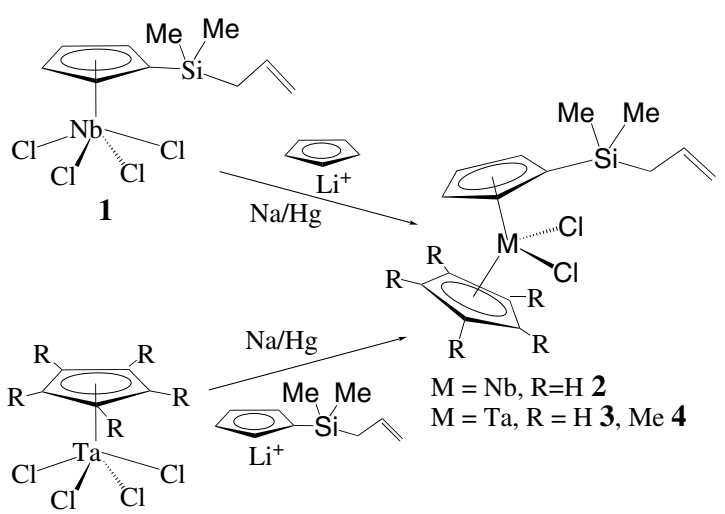




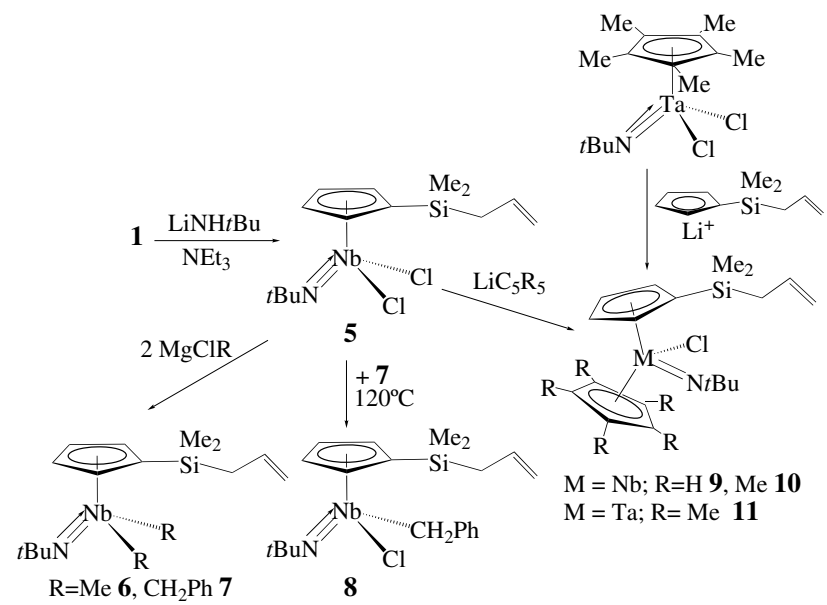

Scheme 4.

unique component in $90 \%$ yield by a redistribution reaction when an equimolar mixture of 5 and 7 was heated in toluene at $120^{\circ} \mathrm{C}$. The alkyl complexes 6-8 were isolated as waxy brown air sensitive solids, very soluble in all organic solvents including hexanes. They were characterized by elemental analyses and NMR spectroscopy.

Similar alkylation using 1 equiv of $\operatorname{Li}\left(\mathrm{C}_{5} \mathrm{R}_{5}\right)(\mathrm{R}=\mathrm{H}$, $\mathrm{Me})$ gave the dicyclopentadienyl imido complexes $\left[\mathrm{Nb}\left(\eta^{5}-\mathrm{C}_{5} \mathrm{R}_{5}\right)\left\{\eta^{5}-\mathrm{C}_{5} \mathrm{H}_{4} \mathrm{SiMe}_{2}\left(\mathrm{CH}_{2} \mathrm{CH}=\mathrm{CH}_{2}\right)\right\}(\mathrm{N} t \mathrm{Bu})-\right.$ $\mathrm{Cl}](\mathrm{R}=\mathrm{H}$ 9, Me 10) isolated in 75\% yield as yellow and waxy brown solids, respectively. The related tantalum complex $\quad\left[\mathrm{Ta}\left(\eta^{5}-\mathrm{C}_{5} \mathrm{Me}_{5}\right)\left\{\eta^{5}-\mathrm{C}_{5} \mathrm{H}_{4} \mathrm{SiMe}_{2}\left(\mathrm{CH}_{2} \mathrm{CH}=\right.\right.\right.$ $\left.\left.\left.\mathrm{CH}_{2}\right)\right\}(\mathrm{N} t \mathrm{Bu}) \mathrm{Cl}\right] \mathbf{1 1}$ was isolated as a brown waxy solid in $70 \%$ yield by a similar reaction of the corresponding $\left[\mathrm{Ta}\left(\eta^{5}-\mathrm{C}_{5} \mathrm{Me}_{5}\right)(\mathrm{N} t \mathrm{Bu}) \mathrm{Cl}_{2}\right]$ [18] with the lithium salt of the allylsilylcyclopentadienyl ligand. Complexes 9-11 were very soluble in all usual organic solvents including hexanes. They were identified by elemental analyses and NMR spectroscopy.

\subsection{Structural studies}

The metal(IV) complexes 2-4 are paramagnetic compounds with effective magnetic moments $\mu_{\mathrm{ef}}=1.7-1.8$ $\mathrm{BM}$ at $298 \mathrm{~K}$ similar to those found for related compounds.

All of the other metal(V) compounds were studied by ${ }^{1} \mathrm{H}$ and ${ }^{13} \mathrm{C}$ NMR spectroscopy and selected data are shown in Section 3. The tetrachloro (1), dichloro-imido (5) and dialkyl-imido (6-7) complexes are $C_{\mathrm{s}}$ symmetry molecules which show the expected ${ }^{1} \mathrm{H}$ NMR spectra corresponding to an $\mathrm{AA}^{\prime} \mathrm{BB}^{\prime}$ spin system for the ring protons. The typical spectral pattern of the allyldimethylsilyl group consists of two high field signals observed as one singlet for both equivalent silicon methyl groups and one doublet for the methylene silicon-bound group, together with three low field signals appearing as two doublets for the olefinic methylene group and one multiplet due to the internal olefinic proton. The ring proton resonances are shifted upfield for imido complexes (5-8) compared with the tetrachloro niobium derivative 1, whereas the resonances due to $\mathrm{SiMe}_{2}, \mathrm{Si}-$ $\mathrm{CH}_{2}$ and olefinic $\mathrm{CH}=\mathrm{CH}_{2}$ protons of the dimethylsilylallyl group are shifted low field, the $\mathrm{Si}-\mathrm{CH}_{2}$ being the most sensitive signals. These displacements are related to the stronger $\sigma-\pi$-donating character of the imido ligand, causing the metal to require less electron density from the aromatic ring. The same behavior can be observed in the ${ }^{13} \mathrm{C}$ NMR spectra, although smaller differences are found. The electron donating capacity of the imido ligand can be inferred [19] from the $\Delta \delta=\delta$ (quaternary $\mathrm{C})-\delta$ (methyl $\mathrm{C}$ ) differences observed for the tert-butyl group in the ${ }^{13} \mathrm{C}$ NMR spectra which are between 33.0 (6) and 39.7 (5), in the range accepted for a substantial $\pi$-donating contribution (see Table 1). The ${ }^{1} \mathrm{H}$ and ${ }^{13} \mathrm{C}$ NMR spectra of complex 8 show similar resonances for the tert-butyl and olefin groups although the chiral character of the metal center makes all of the other substituents non-equivalent. Therefore, it shows two singlets for the methyl-silyl groups, two overlapped doublets for the methylene-silyl protons and two doublets for the methylene-benzyl protons. Consequently, there are four ${ }^{1} \mathrm{H}$ multiplets and five ${ }^{13} \mathrm{C}$ resonances for the silyl-substituted ring.

All of the dicyclopentadienyl imido complexes 9-11 are chiral asymmetric molecules which show the expected similar pattern observed for 8 in their ${ }^{1} \mathrm{H}$ and ${ }^{13} \mathrm{C}$ NMR spectra. The nature of these apparently 20 electron compounds has been reported [20] previously for similar group 5 and 6 metal derivatives, which show nearly linear $\mathrm{M}-\mathrm{N}-\mathrm{R}$ imido ligands with the sp hybridized nitrogen acting as a four-electron donor ligand. Theoretical investigation of the bonding in compounds of this type showed that the surplus electron pair is located in an essentially cyclopentadienyl-based orbital. We were not able to isolate single crystals appropriate for X-ray diffraction studies. Nevertheless, the $\pi$-donor capacity of the imido ligand in complexes 9-11 can be estimated by the $\Delta \delta$ values observed in their ${ }^{13} \mathrm{C} \mathrm{NMR}$ spectra for the tert-butyl substituent.

As shown in Table 1, complex 9 shows a value of $\Delta \delta$ (40.0), even higher than that found for complex 5, indicating the strong $\pi$-bonding contribution of the imido ligand. As expected, this contribution is lower for the niobium complex $10(\Delta \delta=38.5)$ and even lower for the tantalum complex $11(\Delta \delta=33.7)$ with its more donating $\mathrm{Cp}^{*}$ ligand.

\section{Experimental}

Standard Schlenk procedures were used for all syntheses and sample manipulations. The solvents were 
Table 1

${ }^{13} \mathrm{C}\left\{{ }^{1} \mathrm{H}\right\}$ NMR data in $\mathrm{C}_{6} \mathrm{D}_{6}$ for the tert-butyl-imido group in compounds 5-11

\begin{tabular}{llll}
\hline Compound & $\delta C \mathrm{Me}_{3}$ & $\delta \mathrm{CMe}_{3}$ & $\Delta \delta$ \\
\hline $\mathbf{5}$ & 30.4 & 70.1 & 39.7 \\
$\mathbf{6}$ & 32.2 & 65.2 & 33.0 \\
$\mathbf{7}$ & 31.9 & 66.5 & 34.6 \\
$\mathbf{8}$ & 31.1 & 68.0 & 36.9 \\
$\mathbf{9}$ & 29.9 & 69.9 & 40.0 \\
$\mathbf{1 0}$ & 31.3 & 69.8 & 38.5 \\
$\mathbf{1 1}$ & 32.8 & 66.5 & 33.7 \\
\hline
\end{tabular}

dried by standard methods (hexane over $\mathrm{Na} / \mathrm{K}$ alloy, toluene and THF over sodium) and distilled under argon before use. $\mathrm{Na}, \mathrm{Hg}, \mathrm{C}_{5} \mathrm{H}_{6}, \mathrm{SiMe}_{2}\left(\mathrm{CH}_{2} \mathrm{CH}=\mathrm{CH}_{2}\right) \mathrm{Cl}$, $\mathrm{SiMe}_{3} \mathrm{Cl}, \mathrm{Li} n \mathrm{Bu}\left(1.6 \mathrm{M}\right.$ in hexane), $\mathrm{TaCl}_{5}, \mathrm{NbCl}_{5}$, $\mathrm{NH}_{2} t \mathrm{Bu}, \mathrm{NEt}_{3}, \mathrm{MgCl}\left(\mathrm{CH}_{2} \mathrm{Ph}\right)(2 \mathrm{M}$ in $\mathrm{THF})$ and $\mathrm{MgClMe}(3 \mathrm{M}$ in THF) were obtained from Aldrich and used without further purification. $\mathrm{Na}\left(\mathrm{C}_{5} \mathrm{H}_{5}\right)$ [21], Si$\mathrm{Me}_{3}\left(\mathrm{C}_{5} \mathrm{H}_{5}\right)$ [22], $\mathrm{LiNH} t \mathrm{Bu},{ }^{1}\left[\mathrm{Ta}\left(\eta^{5}-\mathrm{C}_{5} \mathrm{H}_{5}\right) \mathrm{Cl}_{4}\right]$ [23], $\mathrm{Li}\left(\mathrm{C}_{5} \mathrm{H}_{5}\right)$ [24], $\left[\mathrm{Ta}\left(\eta^{5}-\mathrm{C}_{5} \mathrm{Me}_{5}\right) \mathrm{CI}_{4}\right]$ [25] and [Ta( $\eta^{5}-$ $\left.\mathrm{C}_{5} \mathrm{Me}_{5}\right) \mathrm{Cl}_{2}(\mathrm{NtBu})$ ] [26] were prepared as described previously.

IR spectra were recorded on a Perkin-Elmer 583 spectrophotometer $\left(4000-200 \mathrm{~cm}^{-1}\right)$ as Nujo1 mulls between CsI pellets. ${ }^{1} \mathrm{H}$ and ${ }^{13} \mathrm{C}\{\mathrm{H}\}$ NMR spectra were recorded on a Varian VXR-300 Unity instrument in $\mathrm{C}_{6} \mathrm{D}_{6}$ solution at $300 \mathrm{~K}$ and chemical shifts are reported in $\delta$ units relative to the solvent signals $\left(\delta_{\mathrm{H}} 7.15, \delta_{\mathrm{C}}\right.$ 128.00). $\mathrm{C}, \mathrm{H}$ and $\mathrm{N}$ analyses were performed with a Perkin-Elmer 240 microanalyzer.

\subsection{Preparation of $\left[\mathrm{Nb}\left\{\eta^{5}-\mathrm{C}_{5} \mathrm{H}_{4} \mathrm{SiMe}_{2}\left(\mathrm{CH}_{2} \mathrm{CH}=\right.\right.\right.$ $\left.\left.\left.\mathrm{CH}_{2}\right)\right\} \mathrm{Cl}_{4}\right](\mathbf{1})$}

A solution of 1,1-[SiMe 2 (allyl) $]_{2} \mathrm{C}_{5} \mathrm{H}_{4}(3.5 \mathrm{ml}, 22.4$ mmol) was added to a toluene suspension $(75 \mathrm{ml})$ of $\mathrm{NbCl}_{5}(3 \mathrm{~g}, 11.1 \mathrm{mmol})$ and the mixture was vigorously stirred for $12 \mathrm{~h}$ at room temperature. The red suspension was filtered and the red solid was washed twice with $n$ hexane $(2 \times 15 \mathrm{ml})$, dried in vacuo and identified as $\mathbf{1}$. Yield: $3.5 \mathrm{~g}, 8.8 \mathrm{mmol}(80 \%)$. ${ }^{1} \mathrm{H}$ NMR $\left(\mathrm{C}_{6} \mathrm{D}_{6}\right): \delta 0.17$ (s, 6H, SiMe $), 1.40\left(\mathrm{~d},{ }^{3} J=8.1 \mathrm{~Hz}, 2 \mathrm{H}, \mathrm{SiCH}_{2}\right), 4.65$ $\left(\mathrm{d},{ }^{3} J_{\text {trans }}=16.1 \mathrm{~Hz}, 1 \mathrm{H}, \mathrm{CH}=\mathrm{CH} H_{2}\right), 4.78\left(\mathrm{~d},{ }^{3} J_{\text {cis }}=9.9\right.$ $\left.\mathrm{Hz}, 1 \mathrm{H}, \mathrm{CH}=\mathrm{CH}_{2}\right), 5.41\left(\mathrm{~m}, 1 \mathrm{H}, \mathrm{CH}=\mathrm{CH}_{2}\right), 6.31(\mathrm{~m}$, $\left.2 \mathrm{H}, \mathrm{C}_{5} H_{4}\right), 6.44\left(\mathrm{~m}, 2 \mathrm{H}, \mathrm{C}_{5} H_{4}\right) .{ }^{13} \mathrm{C} \mathrm{NMR}\left(\mathrm{C}_{6} \mathrm{D}_{6}\right): \delta-$ $3.4\left(\mathrm{SiMe}{ }_{2}\right), 24.0\left(\mathrm{SiCH}_{2}\right), 113.1\left(\mathrm{CH}=\mathrm{CH}_{2}\right), 133.1$ $\left(\mathrm{CH}=\mathrm{CH}_{2}\right), 115.1 \quad\left(C_{5} \mathrm{H}_{4}\right), 127.8 \quad\left(C_{5} \mathrm{H}_{4}\right) . \quad \operatorname{IR}\left(\mathrm{cm}^{-1}\right)$ : $3030 \mathrm{w}, 1460 \mathrm{~m}, 1048 \mathrm{~s}, 803 \mathrm{~m}, 1255 \mathrm{~s}, 579 \mathrm{~m}, 1627 \mathrm{~s}$, 994w, 489s, 349m. Elemental Anal. Calc. for $\mathrm{C}_{10} \mathrm{H}_{15} \mathrm{Cl}_{4} \mathrm{NbSi}$ (398.03): C, 30.18; H, 3.80. Found: C, $30.32 ; \mathrm{H}, 3.91 \%$.

\footnotetext{
${ }^{1}$ Quantitative yield by reaction of $\mathrm{NH}_{2} \mathrm{t} \mathrm{Bu}$ with $\mathrm{Lin} \mathrm{Bu}$.
}

3.2. Preparation of $\left[\mathrm{Nb}\left\{\eta^{5}-\mathrm{C}_{5} \mathrm{H}_{4} \mathrm{SiMe}_{2}\left(\mathrm{CH}_{2} \mathrm{CH}=\right.\right.\right.$ $\left.\left.\left.\mathrm{CH}_{2}\right)\right\}\left(\eta^{5}-\mathrm{C}_{5} \mathrm{H}_{5}\right) \mathrm{Cl}_{2}\right]$ (2)

Toluene $(150 \mathrm{ml})$ was added to a mixture of $\mathbf{1}(1.38 \mathrm{~g}$, $3.4 \mathrm{mmol})$ and $\mathrm{Li}\left(\mathrm{C}_{5} \mathrm{H}_{5}\right)(0.25 \mathrm{~g}, 3.4 \mathrm{mmol})$. This suspension was added to a $10 \%$ sodium amalgam $(0.08 \mathrm{~g}$, $3.4 \mathrm{mmol}$ ). The mixture was stirred for $16 \mathrm{~h}$ at room temperature. The resulting brown suspension was decanted and filtered through Celite, and the filtrate was concentrated to ca. $15 \mathrm{ml}$ and cooled to $-40{ }^{\circ} \mathrm{C}$ to give 2 as a dark brown solid. Yield: $0.93 \mathrm{~g}, 2.37 \mathrm{mmol}(70 \%)$. IR $\left(\mathrm{cm}^{-1}\right)$ : 3074w, 1461m, 1050s, 804m, 1251s, 576m, $1627 \mathrm{~s}, 960 \mathrm{w}, 489 \mathrm{~s}, 285 \mathrm{~s}$. Elemental Anal. Calc. for $\mathrm{C}_{15} \mathrm{H}_{20} \mathrm{Cl}_{2} \mathrm{NbSi}$ (392.22): C, 45.93; H, 5.14. Found: $\mathrm{C}$, 45.78; H, 5.10\%.

\subsection{Preparation of $\left[\mathrm{Ta}\left\{\eta^{5}-\mathrm{C}_{5} \mathrm{H}_{4} \mathrm{SiMe}_{2}\left(\mathrm{CH}_{2} \mathrm{CH}=\right.\right.\right.$ $\left.\left.\left.\mathrm{CH}_{2}\right)\right\}\left(\eta^{5}-\mathrm{C}_{5} \mathrm{R}_{5}\right) \mathrm{Cl}_{2}\right](\mathrm{R}=\mathrm{H}, \mathrm{3} ; \mathrm{Me}, 4)$}

Toluene $(150 \mathrm{ml})$ was added to a mixture of $\left[\mathrm{Ta}\left(\eta^{5}\right.\right.$ $\left.\left.\mathrm{C}_{5} \mathrm{R}_{5}\right) \mathrm{Cl}_{4}\right],(\mathrm{R}=\mathrm{H}, 1.68 \mathrm{~g}, 4.35 \mathrm{mmol} ; \mathrm{R}=\mathrm{Me}, 2.0 \mathrm{~g}$, $4.35 \mathrm{mmol})$ and $\mathrm{Li}_{5} \mathrm{C}_{5} \mathrm{H}_{4} \mathrm{SiMe}_{2}$ (allyl)] $(0.74 \mathrm{~g}, 4.35$ mmol). This suspension was added to a $10 \%$ sodium amalgam $(0.1 \mathrm{~g}, 4.35 \mathrm{mmol})$. The mixture was stirred for $16 \mathrm{~h}$ at room temperature. The resulting brown or green suspension was decanted and filtered through Celite, and the filtrate was concentrated to ca. $15 \mathrm{ml}$ and cooled to $-40{ }^{\circ} \mathrm{C}$ to give 3 as a dark brown solid or 4 as dark green crystals.

Data for compound 3: Yield: $1.46 \mathrm{~g}, 3,04 \mathrm{mmol}$ $(70 \%)$. IR $\left(\mathrm{cm}^{-1}\right): 3095 \mathrm{w}, 1461 \mathrm{~m}, 1017 \mathrm{~s}, 824 \mathrm{~s}, 1250 \mathrm{~s}$, $1627 \mathrm{~s}, 899 \mathrm{~m}, 400 \mathrm{w}, 274 \mathrm{~s}$. Elemental Anal. Calc. for $\mathrm{C}_{15} \mathrm{H}_{20} \mathrm{Cl}_{2} \mathrm{SiTa}$ (480.26): C, 37.51; H, 4.20. Found: C, $37.65 ; \mathrm{H}, 4.32 \%$.

Data for compound 4: Yield: $1.79 \mathrm{~g}, 3.25 \mathrm{mmol}$ (75\%). IR $\left(\mathrm{cm}^{-1}\right)$ : $3080 \mathrm{w}, 1461 \mathrm{~s}, 1029 \mathrm{~s}, 1051 \mathrm{~s}, 821 \mathrm{~m}$, 1243s, 574w, 1628s, 918m, 444m, 274s. Elemental Anal. Calc. for $\mathrm{C}_{20} \mathrm{H}_{30} \mathrm{Cl}_{2} \mathrm{SiTa}$ (550.40): C, 43.64; H, 5.49. Found: C, 43.68; H, 5.65\%.

\subsection{Preparation of $\left[\mathrm{Nb}\left\{\eta^{5}-\mathrm{C}_{5} \mathrm{H}_{4} \mathrm{SiMe}_{2}\left(\mathrm{CH}_{2} \mathrm{CH}=\right.\right.\right.$ $\left.\left.\left.\mathrm{CH}_{2}\right)\right\} \mathrm{Cl}_{2}(\mathrm{NtBu})\right]$ (5)}

A hexane solution $(50 \mathrm{ml})$ of $\mathrm{LiNH} t \mathrm{Bu}(0.3 \mathrm{~g}, 3.7$ mmol) was added at $-78{ }^{\circ} \mathrm{C}$ to a toluene suspension $(50 \mathrm{ml})$ of $\mathbf{1}(1.5 \mathrm{~g}, 3.7 \mathrm{mmol})$ and $\mathrm{NEt}_{3}(0.52 \mathrm{ml}, 3.7$ $\mathrm{mmol}$ ). The mixture was stirred for $15 \mathrm{~h}$ at room temperature. The resulting brown suspension was concentrated under reduced pressure and hexane $(50 \mathrm{ml})$ was added. The suspension was filtered through Celite and the filtrate was concentrated to ca. $10 \mathrm{ml}$ and cooled to $-40{ }^{\circ} \mathrm{C}$ to give 5 as a yellow solid. Yield: $1.00 \mathrm{~g}$, $2.51 \mathrm{mmol}(70 \%) .{ }^{1} \mathrm{H}$ NMR $\left(\mathrm{C}_{6} \mathrm{D}_{6}\right): \delta 0.29(\mathrm{~s}, 6 \mathrm{H}$, $\mathrm{SiMe} 2), 1.06\left(\mathrm{~s}, 9 \mathrm{H}, \mathrm{CM} e_{3}\right), 1.66\left(\mathrm{~d},{ }^{3} J=8.0 \mathrm{~Hz}, 2 \mathrm{H}\right.$, $\left.\mathrm{SiCH}_{2}\right), \quad 4.85\left(\mathrm{~m}, 2 \mathrm{H}, \mathrm{CH}=\mathrm{CH}_{2}\right), \quad 5.62(\mathrm{~m}, 1 \mathrm{H}$, $\left.\mathrm{C} H=\mathrm{CH}_{2}\right), 6.09\left(\mathrm{~m}, 2 \mathrm{H}, \mathrm{C}_{5} H_{4}\right), 6.35\left(\mathrm{~m}, 2 \mathrm{H}, \mathrm{C}_{5} H_{4}\right)$; 
${ }^{13} \mathrm{C}$ NMR $\left(\mathrm{C}_{6} \mathrm{D}_{6}\right): \delta-2.8(\mathrm{SiMe}), 24.1\left(\mathrm{SiCH}_{2}\right), 30.4$ $\left(\mathrm{CMe}_{3}\right), \quad 70.1 \quad\left(\mathrm{CMe}_{3}\right), \quad 114.3 \quad\left(\mathrm{CH}=\mathrm{CH}_{2}\right), \quad 134.1$ $\left(C \mathrm{H}=\mathrm{CH}_{2}\right), 110.3\left(C_{5} \mathrm{H}_{4}\right), 122.6\left(C_{5} \mathrm{H}_{4}\right), 124.5\left(C_{5} \mathrm{H}_{4}\right.$, $\left.\mathrm{C}_{\mathrm{i}}\right)$. IR $\left(\mathrm{cm}^{-1}\right): 2964 \mathrm{~m}, 1450 \mathrm{~m}, 1036 \mathrm{~s}, 824 \mathrm{~m}, 1256 \mathrm{~s}$, 1368s, 570m, 1626s, 925w, 425w, 374w. Elemental Anal. Calc. for $\mathrm{C}_{14} \mathrm{H}_{24} \mathrm{Cl}_{2} \mathrm{NNbSi}$ (398.25): C, 42.22; $\mathrm{H}, 6.07$; N, 3.52. Found: C, 42.26; H, 6.07; N, 3.67\%.

3.5. Preparation of $\left[\mathrm{Nb}\left\{\eta^{5}-\mathrm{C}_{5} \mathrm{H}_{4} \mathrm{SiMe}_{2}\left(\mathrm{CH}_{2} \mathrm{CH}=\right.\right.\right.$ $\left.\left.\left.\mathrm{CH}_{2}\right)\right\} R_{2}(\mathrm{NtBu})\right] \mathrm{R}=\mathrm{Me}, 6 ; \mathrm{CH}_{2} \mathrm{Ph}, 7$

A THF solution of $\mathrm{MgClR}(\mathrm{R}=\mathrm{Me}, 2.3 \mathrm{ml}, 6.8$ mmol; $\left.\mathrm{R}=\mathrm{CH}_{2} \mathrm{Ph}, 3.4 \mathrm{ml}, 6.8 \mathrm{mmol}\right)$ was added at $-78{ }^{\circ} \mathrm{C}$ to a hexane solution $(50 \mathrm{ml})$ of $5(1.37 \mathrm{~g}, 3.4$ $\mathrm{mmol})$. The mixture was stirred for $2 \mathrm{~h}$ at room temperature. The resulting brown suspension was decanted and filtered through Celite, and the filtrate was concentrated under reduced pressure to give $\mathbf{6}$ (reddish) and 7 (brown) as viscous products.

Data for compound 6: Yield: $0.85 \mathrm{~g}, 2.38 \mathrm{mmol}$ $(70 \%) .{ }^{1} \mathrm{H}$ NMR $\left(\mathrm{C}_{6} \mathrm{D}_{6}\right): \delta 0.19\left(\mathrm{~s}, 6 \mathrm{H}, \mathrm{Si} M e_{2}\right), 0.55(\mathrm{~s}$, $6 \mathrm{H}, \mathrm{NbMe}$ ), 1.32 (s, 9H, CMe $), 1.63\left(\mathrm{~d},{ }^{3} \mathrm{~J}=7.9 \mathrm{~Hz}\right.$, $\left.2 \mathrm{H}, \mathrm{SiCH}_{2}\right), 4.88\left(\mathrm{~m}, 2 \mathrm{H}, \mathrm{CH}=\mathrm{CH}_{2}\right), 5.73(\mathrm{~m}, 1 \mathrm{H}$, $\left.\mathrm{C} H=\mathrm{CH}_{2}\right), 5.75\left(\mathrm{~m}, 2 \mathrm{H}, \mathrm{C}_{5} H_{4}\right), 6.05\left(\mathrm{~m}, 2 \mathrm{H}, \mathrm{C}_{5} H_{4}\right)$. ${ }^{13} \mathrm{C}$ NMR $\left(\mathrm{C}_{6} \mathrm{D}_{6}\right): \delta-2.4(\mathrm{SiMe}), 24.8\left(\mathrm{SiCH}_{2}\right), 32.2$ $\left(\mathrm{CMe}_{3}\right), \quad 65.2 \quad\left(\mathrm{CMe}_{3}\right), \quad 113.9 \quad\left(\mathrm{CH}=\mathrm{CH}_{2}\right), \quad 134.5$ $\left(C \mathrm{H}=\mathrm{CH}_{2}\right), 108.0\left(C_{5} \mathrm{H}_{4}\right), 114.1\left(C_{5} \mathrm{H}_{4}\right), 117.8\left(C_{5} \mathrm{H}_{4}\right.$, $\left.\mathrm{C}_{\mathrm{i}}\right)$. IR $\left(\mathrm{cm}^{-1}\right): 2966 \mathrm{~s}, 1450 \mathrm{~m}, 1045 \mathrm{~s}, 816 \mathrm{~s}, 1252 \mathrm{~s}$, 1354s, 546m, 1629s, 931m, 433w, 401w. Elemental Anal. Calc. for $\mathrm{C}_{16} \mathrm{H}_{30} \mathrm{NNbSi}(357.41)$ : $\mathrm{C}, 53.77 ; \mathrm{H}, 8.46 ; \mathrm{N}$, 3.92. Found: C, 53.94; H, 8.59; N, 3.74\%.

Data for compound 7: Yield: $1.38 \mathrm{~g}, 2.71 \mathrm{mmol}$ $(80 \%) .{ }^{1} \mathrm{H}$ NMR $\left(\mathrm{C}_{6} \mathrm{D}_{6}\right): \delta 0.23\left(\mathrm{~s}, 6 \mathrm{H}, \mathrm{Si} M e_{2}\right), 1.12(\mathrm{~s}$, $9 \mathrm{H}, \mathrm{CMe}), 1.62\left(\mathrm{~d},{ }^{2} \mathrm{~J}=8.0 \mathrm{~Hz}, 4 \mathrm{H}, \mathrm{NbCH}_{2} \mathrm{Ph}\right), 1.91$ (d, $\left.{ }^{3} \mathrm{~J}=8.0 \mathrm{~Hz}, 2 \mathrm{H}, \mathrm{SiCH}_{2}\right), 4.91\left(\mathrm{~m}, 2 \mathrm{H}, \mathrm{CH}=\mathrm{CH}_{2}\right)$, $5.52\left(\mathrm{~m}, 2 \mathrm{H}, \mathrm{C}_{5} H_{4}\right), 5.70\left(\mathrm{~m}, 1 \mathrm{H}, \mathrm{CH}=\mathrm{CH}_{2}\right), 5.82(\mathrm{~m}$, $\left.2 \mathrm{H}, \mathrm{C}_{5} H_{4}\right), 6.86-7.04\left(\mathrm{~m}, 10 \mathrm{H}, \mathrm{C}_{6} H_{5}\right) ;{ }^{13} \mathrm{C} \mathrm{NMR}$ $\left(\mathrm{C}_{6} \mathrm{D}_{6}\right): \delta$-2.3 $(\mathrm{SiMe}), 25.4\left(\mathrm{SiCH}_{2}\right), 31.9\left(\mathrm{CMe}_{3}\right), 66.5$ $\left(\mathrm{CMe}_{3}\right), 41.5\left(\mathrm{NbCH} \mathrm{H}_{2} \mathrm{Ph}\right), 113.9\left(\mathrm{CH}=\mathrm{CH}_{2}\right), 107.3$ $\left(C_{5} \mathrm{H}_{4}\right), 134.6\left(C \mathrm{H}=\mathrm{CH}_{2}\right), 113.3\left(C_{5} \mathrm{H}_{4}\right), 113.0\left(C_{5} \mathrm{H}_{4}\right.$, $\left.\mathrm{C}_{\mathrm{i}}\right), 124.9,128.7,130.3\left(C_{6} \mathrm{H}_{5}\right), 140.1\left(C_{6} \mathrm{H}_{5}, \mathrm{C}_{\mathrm{i}}\right) \mathrm{IR}$ $\left(\mathrm{cm}^{-1}\right): 3057 \mathrm{~m}, 1417 \mathrm{~m}, 1085 \mathrm{~s}, 819 \mathrm{~s}, 1210 \mathrm{~s}, 1354 \mathrm{~s}$, 549m, 1629s, 960m, 436m, 377w. Elemental Anal. Calc. for $\mathrm{C}_{28} \mathrm{H}_{38} \mathrm{NNbSi}(509.61)$ : C, 65.99; H, 7.52; N, 2.75 . Found: C, 65.67; H, 7.39; N, 2.71\%.

\subsection{Preparation of $\left[\mathrm{Nb}\left(\eta^{5}-\mathrm{C}_{5} \mathrm{H}_{5}\right)\left\{\eta^{5}-\mathrm{C}_{5} \mathrm{H}_{4} \mathrm{SiMe}_{2}\left(\mathrm{CH}_{2}\right.\right.\right.$ - $\left.\left.\left.\mathrm{CH}=\mathrm{CH}_{2}\right)\right\}\left(\mathrm{CH}_{2} \mathrm{Ph}\right) \mathrm{Cl}\right](\boldsymbol{8})$}

Toluene $(50 \mathrm{ml})$ was added to a mixture of $5(2.0 \mathrm{~g}$, $5.02 \mathrm{mmol})$ and $7(2.56 \mathrm{~g}, 5.02 \mathrm{mmol})$. The mixture was heated to $120^{\circ} \mathrm{C}$ for $5 \mathrm{~h}$ and the solvent was evaporated under reduced pressure. The residue was treated with hexane $(30 \mathrm{ml})$ and the solution was filtered and concentrated under vacuum to give $\mathbf{8}$ as a brown viscous product. Yield: $2.0 \mathrm{~g}, 4.47 \mathrm{mmol}(90 \%) .{ }^{1} \mathrm{H}$ NMR
$\left(\mathrm{C}_{6} \mathrm{D}_{6}\right): \delta 0.26\left(\mathrm{~s}, 3 \mathrm{H}, \mathrm{Si} M e_{2}\right), 0.29$ (s, 3H, SiMe $)$, $1.12(\mathrm{~s}, 9 \mathrm{H}, \mathrm{CMe}), 1.67\left(\mathrm{~d},{ }^{3} J=8.0 \mathrm{~Hz}, 2 \mathrm{H}, \mathrm{SiCH}_{2}\right)$, $2.84\left(\mathrm{~d},{ }^{2} J=8.0 \mathrm{~Hz}, 1 \mathrm{H}, \mathrm{NbCH}_{2} \mathrm{Ph}\right), 3.22\left(\mathrm{~d},{ }^{2} J=8.0\right.$ $\left.\mathrm{Hz}, 1 \mathrm{H}, \mathrm{NbCH}_{2} \mathrm{Ph}\right), 4.93\left(\mathrm{~m}, 2 \mathrm{H}, \mathrm{CH}=\mathrm{CH}_{2}\right), 5.70(\mathrm{~m}$, $\left.1 \mathrm{H}, \mathrm{C}_{5} H_{4}\right), 5.76\left(\mathrm{~m}, 1 \mathrm{H}, \mathrm{CH}=\mathrm{CH}_{2}\right), 5.88(\mathrm{~m}, 2 \mathrm{H}$, $\left.\mathrm{C}_{5} H_{4}\right), 6.05\left(\mathrm{~m}, 1 \mathrm{H}, \mathrm{C}_{5} H_{4}\right), 6.87\left(\mathrm{~d},{ }^{3} J=7.7 \mathrm{~Hz}, 2 \mathrm{H}_{\mathrm{o}}\right.$, $\left.\mathrm{C}_{6} H_{5}\right), 7.05\left(\mathrm{t},{ }^{3} J=7.7 \mathrm{~Hz}, 2 \mathrm{H}_{\mathrm{m}}, \mathrm{C}_{6} H_{5}\right), 7.22(\mathrm{t}$, $\left.{ }^{3} J=7.7 \mathrm{~Hz}, \quad 2 \mathrm{H}_{\mathrm{p}} \mathrm{C}_{6} H_{5}\right) ;{ }^{13} \mathrm{C} \quad \mathrm{NMR} \quad\left(\mathrm{C}_{6} \mathrm{D}_{6}\right): \delta-2.4$ $\left(\mathrm{Si} \mathrm{Me}_{2}\right),-2.5(\mathrm{SiMe}), 24.8\left(\mathrm{SiCH}_{2}\right), 31.1\left(\mathrm{CMe}_{3}\right), 68.0$ $\left(\mathrm{CMe}_{3}\right), 51.6\left(\mathrm{NbCH}_{2} \mathrm{Ph}\right), 113.7\left(\mathrm{CH}=\mathrm{CH}_{2}\right), 106.3$ $\left(C_{5} \mathrm{H}_{4}\right), 134.7\left(\mathrm{CH}=\mathrm{CH}_{2}\right), 109.7\left(C_{5} \mathrm{H}_{4}\right), 111.8\left(C_{5} \mathrm{H}_{4}\right)$, $119.7\left(C_{5} \mathrm{H}_{4}\right), 118.5\left(C_{5} \mathrm{H}_{4}, \mathrm{C}_{\mathrm{i}}\right), 128.5 ; 128.7,129.9$; $131.5\left(C_{6} \mathrm{H}_{5}\right)$ IR $\left(\mathrm{cm}^{-1}\right): 3074 \mathrm{~s}, 1449 \mathrm{~m}, 1046 \mathrm{~m}, 819 \mathrm{~m}$, $1247 \mathrm{~s}, 1356 \mathrm{~s}, 548 \mathrm{~m}, 1620 \mathrm{~s}, 929 \mathrm{~m}, 431 \mathrm{~m}, 353 \mathrm{w}, 375 \mathrm{w}$. Elemental Anal. Calc. for $\mathrm{C}_{22} \mathrm{H}_{27} \mathrm{ClNbSi}$ (447.90): C, 59.00; H, 6.08. Found: C, 59.14; H, 6.21\%.

\subsection{Preparation of $\left[\mathrm{Nb}\left\{\eta^{5}-\mathrm{C}_{5} \mathrm{H}_{4} \mathrm{SiMe}_{2}\left(\mathrm{CH}_{2} \mathrm{CH}=\right.\right.\right.$ $\left.\left.\left.\mathrm{CH}_{2}\right)\right\}\left(\eta^{5}-\mathrm{C}_{5} \mathrm{H}_{5}\right) \mathrm{Cl}(\mathrm{NtBu})\right]$ (9)}

Hexane $(50 \mathrm{ml})$ was added to a mixture of $5(0.4 \mathrm{~g}, 1.0$ mmol) and $\mathrm{LiC}_{5} \mathrm{H}_{5}(0.072 \mathrm{~g}, 1.0 \mathrm{mmol})$ cooled to -78 ${ }^{\circ} \mathrm{C}$. After stirring overnight at room temperature, the yellow suspension was decanted and filtered through Celite. The filtrate was concentrated to ca. $10 \mathrm{ml}$ and cooled to $-40{ }^{\circ} \mathrm{C}$ to give 9 as a yellow solid. Yield: $0.32 \mathrm{~g}, 0.75 \mathrm{mmol}(75 \%) .{ }^{1} \mathrm{H}$ NMR $\left(\mathrm{C}_{6} \mathrm{D}_{6}\right): \delta 0.33(\mathrm{~s}$, $3 \mathrm{H}, \mathrm{Si} M e_{2}$ ), 0.40 (s, 3H, Si $M e_{2}$ ), 0.97 (s, 9H, CMe $e_{3}$, $1.74\left(\mathrm{~m}, 2 \mathrm{H}, \mathrm{SiCH}_{2}\right), 4.95\left(\mathrm{~m}, 2 \mathrm{H}, \mathrm{CH}=\mathrm{CH}_{2}\right), 5.76$ $\left(\mathrm{m}, 1 \mathrm{H}, \mathrm{C}_{5} H_{4}\right), 5.80\left(\mathrm{~m}, 1 \mathrm{H}, \mathrm{C} H=\mathrm{CH}_{2}\right), 5.84(\mathrm{~m}, 1 \mathrm{H}$, $\left.\mathrm{C}_{5} H_{4}\right), 5.90\left(\mathrm{~s}, 5 \mathrm{H}, \mathrm{C}_{5} H_{5}\right), 6.22\left(\mathrm{~m}, 1 \mathrm{H}, \mathrm{C}_{5} H_{4}\right), 6.28$ $\left(\mathrm{m}, 1 \mathrm{H}, \mathrm{C}_{5} H_{4}\right) ;{ }^{13} \mathrm{C}$ NMR $\left(\mathrm{C}_{6} \mathrm{D}_{6}\right): \delta-2.3(\mathrm{SiMe} 2),-2.2$ $\left(\mathrm{SiMe}_{2}\right), 25.0\left(\mathrm{SiCH}_{2}\right), 29.9\left(\mathrm{CMe}_{3}\right), 69.9\left(\mathrm{CMe}_{3}\right)$, $114.6\left(\mathrm{CH}=\mathrm{CH}_{2}\right), \quad 105.3\left(C_{5} \mathrm{H}_{4}\right), 135.0 \quad\left(\mathrm{CH}=\mathrm{CH}_{2}\right)$, $113.6 \quad\left(C_{5} \mathrm{H}_{4}\right), \quad 111.9 \quad\left(C_{5} \mathrm{H}_{5}\right), \quad 121.7\left(C_{5} \mathrm{H}_{4}\right), \quad 125.6$ $\left(C_{5} \mathrm{H}_{4}\right), 118.9\left(C_{5} \mathrm{H}_{4}, \mathrm{C}_{\mathrm{i}}\right)$. IR $\left(\mathrm{cm}^{-1}\right): 3078 \mathrm{~m}, 1450 \mathrm{~m}$, $1046 \mathrm{~s}, 805 \mathrm{w}, 1243 \mathrm{~s}, 1357 \mathrm{~s}, 575 \mathrm{w}, 1628 \mathrm{~s}, 897 \mathrm{~m}, 433 \mathrm{~m}$, 319 w. Elemental Anal. Calc. for $\mathrm{C}_{19} \mathrm{H}_{29} \mathrm{ClNNbSi}$ (427.89): C, 53.33; H, 6.83; N, 3.27. Found: C, 53.51; $\mathrm{H}, 6.97$; N, 3.41\%.

3.8. Preparation of $\left[\mathrm{Nb}\left\{\eta^{5}-\mathrm{C}_{5} \mathrm{H}_{4} \mathrm{SiMe}_{2}\left(\mathrm{CH}_{2} \mathrm{CH}=\right.\right.\right.$ $\left.\left.\left.\mathrm{CH}_{2}\right)\right\}\left(\eta^{5}-\mathrm{C}_{5} \mathrm{Me}_{5}\right) \mathrm{Cl}(\mathrm{NtBu})\right](\mathbf{1 0})$

THF (30 ml) was added to a mixture of $5(0.5 \mathrm{~g}, 1.3$ $\mathrm{mmol})$ and $\mathrm{Li}\left(\mathrm{C}_{5} \mathrm{Me}_{5}\right)(0.18 \mathrm{~g}, 1.3 \mathrm{mmol})$ cooled to -78 ${ }^{\circ} \mathrm{C}$. The mixture was stirred for $15 \mathrm{~h}$ at room temperature and the solvent was removed under vacuum. The residue was treated with hexane and after filtration the solution was concentrated under vacuum to give $\mathbf{1 0}$ as a brown viscous solid. Yield: $0.45 \mathrm{~g}, 0.90 \mathrm{mmol}(70 \%)$. ${ }^{1} \mathrm{H}$ NMR $\left(\mathrm{C}_{6} \mathrm{D}_{6}\right): \delta 0.42\left(\mathrm{~s}, 3 \mathrm{H}, \mathrm{Si} M e_{2}\right), 0.50(\mathrm{~s}, 3 \mathrm{H}$, $\left.\mathrm{Si} M e_{2}\right), 1.09$ (s, 9H, CMe $\left.e_{3}\right), 1.80\left(\mathrm{~d},{ }^{3} J=8.0 \mathrm{~Hz}, 2 \mathrm{H}\right.$, $\left.\mathrm{SiCH}_{2}\right), 1.80\left(\mathrm{~s}, 15 \mathrm{H}, \mathrm{C}_{5} \mathrm{Me}_{5}\right), 4.95\left(\mathrm{~m}, 2 \mathrm{H}, \mathrm{CH}=\mathrm{CH}_{2}\right)$, $5.54\left(\mathrm{~m}, 1 \mathrm{H}, \mathrm{C}_{5} H_{4}\right), 5.86\left(\mathrm{~m}, 1 \mathrm{H}, \mathrm{C}_{5} H_{4}\right), 5.86(\mathrm{~m}, 1 \mathrm{H}$, $\left.\mathrm{C} H=\mathrm{CH}_{2}\right), 6.14\left(\mathrm{~m}, 1 \mathrm{H}, \mathrm{C}_{5} H_{4}\right), 6.39\left(\mathrm{~m}, 1 \mathrm{H}, \mathrm{C}_{5} H_{4}\right)$; 
${ }^{13} \mathrm{C}$ NMR $\left(\mathrm{C}_{6} \mathrm{D}_{6}\right): \delta-2.5\left(\mathrm{Si} M e_{2}\right),-2.4\left(\mathrm{Si} M e_{2}\right), 12.7$ $\left(\mathrm{C}_{5} \mathrm{Me}_{5}\right), 25.3\left(\mathrm{SiCH}_{2}\right), \quad 31.3 \quad\left(\mathrm{CMe}_{3}\right), 69.8 \quad\left(\mathrm{CMe}_{3}\right)$, $120.5\left(C_{5} \mathrm{Me}_{5}\right), 113.3\left(\mathrm{CH}=\mathrm{CH}_{2}\right), 108.8\left(C_{5} \mathrm{H}_{4}\right), 110.0$ $\left(C_{5} \mathrm{H}_{4}\right), 135.5\left(C \mathrm{H}=\mathrm{CH}_{2}\right), 112.6\left(C_{5} \mathrm{H}_{4}\right), 114.3\left(C_{5} \mathrm{H}_{4}\right)$, $130.1\left(C_{5} \mathrm{H}_{4}, \mathrm{C}_{\mathrm{i}}\right)$. IR $\left(\mathrm{cm}^{-1}\right): 3075 \mathrm{~s}, 1447 \mathrm{~m}, 1049 \mathrm{~s}$, $812 \mathrm{~m}, 1248 \mathrm{~s}, 1354 \mathrm{~s}, 572 \mathrm{w}, 1629 \mathrm{~s}, 931 \mathrm{~m}, 432 \mathrm{~m}, 377 \mathrm{w}$. Elemental Anal. Calc. for $\mathrm{C}_{24} \mathrm{H}_{39} \mathrm{ClNNbSi}$ (498.03): C, 57.88; H, 7.89; N, 2.81. Found: C, 58.01; H, 7.95; N, $2.93 \%$.

\subsection{Preparation of $\left[\mathrm{Ta}\left\{\eta^{5}-\mathrm{C}_{5} \mathrm{H}_{4} \mathrm{SiMe}_{2}\left(\mathrm{CH}_{2} \mathrm{CH}=\right.\right.\right.$ $\left.\left.\left.\mathrm{CH}_{2}\right)\right\}\left(\eta^{5}-\mathrm{C}_{5} \mathrm{Me}_{5}\right) \mathrm{Cl}(\mathrm{NtBu})\right](\mathbf{1 1})$}

A THF solution (10 ml) of $\mathrm{LiC}_{5} \mathrm{H}_{4} \mathrm{SiMe}_{2}$ (allyl) $(0.18$ g, $1.09 \mathrm{mmol}$ ) was added at $-78{ }^{\circ} \mathrm{C}$ to a hexane solution $(50 \mathrm{ml})$ of $\left[\mathrm{Ta}\left(\eta^{5}-\mathrm{C}_{5} \mathrm{Me}_{5}\right) \mathrm{Cl}_{2}\left(\mathrm{~N}^{t} \mathrm{Bu}\right)\right](0.50 \mathrm{~g}, \quad 1.09$ mmol). After stirring overnight, the orange suspension was decanted and filtered through Celite. The filtrate was concentrated under vacuum to give $\mathbf{1 1}$ as a brown viscous product. Yield: $0.42 \mathrm{~g}, 0.72 \mathrm{mmol}(70 \%) .{ }^{1} \mathrm{H}$ NMR $\left(\mathrm{C}_{6} \mathrm{D}_{6}\right): \delta 0.36$ (s, 3H, SiMe $), 0.42$ (s, 3H, SiMe 2 ), $1.12\left(\mathrm{~s}, 9 \mathrm{H}, \mathrm{CMe}_{3}\right), 1.80\left(\mathrm{~d},{ }^{3} \mathrm{~J}=8.0 \mathrm{~Hz}, 2 \mathrm{H}, \mathrm{SiCH}_{2}\right)$, $1.88\left(\mathrm{~s}, 15 \mathrm{H}, \mathrm{C}_{5} M e_{5}\right), 4.90\left(\mathrm{~m}, 2 \mathrm{H}, \mathrm{CH}=\mathrm{CH}_{2}\right), 5.60$ $\left(\mathrm{m}, 1 \mathrm{H}, \mathrm{C}_{5} H_{4}\right), 5.80\left(\mathrm{~m}, 1 \mathrm{H}, \mathrm{C}_{5} H_{4}\right), 5.80(\mathrm{~m}, 1 \mathrm{H}$, $\left.\mathrm{C} H=\mathrm{CH}_{2}\right), 6.15\left(\mathrm{~m}, 1 \mathrm{H}, \mathrm{C}_{5} H_{4}\right), 6.40\left(\mathrm{~m}, 1 \mathrm{H}, \mathrm{C}_{5} H_{4}\right)$; ${ }^{13} \mathrm{C}$ NMR $\left(\mathrm{C}_{6} \mathrm{D}_{6}\right): \delta-2.5(\mathrm{SiMe}),-2.4(\mathrm{SiMe}), 12.7$ $\left(\mathrm{C}_{5} \mathrm{Me}_{5}\right), 25.4\left(\mathrm{SiCH}_{2}\right), 32.8 \quad\left(\mathrm{CMe}_{3}\right), 66.5\left(\mathrm{CMe}_{3}\right)$, $119.0\left(C_{5} \mathrm{Me}_{5}\right), 113.2\left(\mathrm{CH}=\mathrm{CH}_{2}\right), 107.3\left(C_{5} \mathrm{H}_{4}\right), 108.5$ $\left(C_{5} \mathrm{H}_{4}\right), 135.4\left(C \mathrm{H}=\mathrm{CH}_{2}\right), 112.5\left(C_{5} \mathrm{H}_{4}\right), 119.7\left(C_{5} \mathrm{H}_{4}\right)$, $114.0\left(C_{5} \mathrm{H}_{4}, \mathrm{C}_{\mathrm{i}}\right)$. IR $\left(\mathrm{cm}^{-1}\right): 3076 \mathrm{~s}, 1450 \mathrm{~m}, 1047 \mathrm{~s}$, 821m, 1245s, 1357s, 574w, 1629s, 921m, 431m, 376w. Elemental Anal. Calc. for $\mathrm{C}_{24} \mathrm{H}_{39} \mathrm{ClNSiTa}$ (586.07): C, 49.19; H, 6.71; N, 2.39. Found: C, 48.98; H, 6.74; N, $2.29 \%$.

\section{Acknowledgment}

Financial support of our work by MCyT (Project MAT2001-1309) is gratefully acknowledged.

\section{References}

[1] (a) Z. Wu, R.F. Jordan, J.L. Petersen, J. Am. Chem. Soc. 117 (1995) 5867 ;

(b) M.V. Galakhov, G. Heinz, P. Royo, Chem. Commun. (1998) 17 ;

(c) J.-F. Carpentier, Z. Wu, C.W. Lee, S. Stroemberg,, J.N. Christopher, R.F. Jordan, J. Am. Chem. Soc. 122 (2000) 7750;

(d) C.P. Casey, T.-Y. Lee, J.A. Tunge, D.W. Carpenetti II, J. Am. Chem. Soc. 123 (2001) 10762;

(e) C.P. Casey, D.W. Carpenetti II, H. Sakurai, Organometallics 20 (2001) 4262;

(f) C.G. Brandow, A. Mendiratta, J.E. Bercaw, Organometallics 20 (2001) 4253.

[2] J. Cano, P. Gómez-Sal, G. Heinz, G. Martínez, P. Royo, Inorg. Chim. Acta 345 (2003) 15.
[3] E.Y.-X. Chen, K.A. Abboud, Organometallics 19 (2000) 5541.

[4] K.S. Cook, W.E. Piers, S.J. Rettig, R. McDonald, Organometallics 19 (2000) 2243.

[5] J.K. Cockroft, V.C. Gibson, J.A.K. Howard, A.D. Poole, U. Siemeling, C. Wilson, Chem. Commun. (1992) 1668.

[6] D.N. Williams, J.P. Mitchell, A.D. Poole, U. Siemeling, W. Clegg, D.C.R. Hockless, P.A. O'Neil, V.C. Gibson, J. Chem. Soc., Dalton Trans. (1992) 739.

[7] M.J. Humphries, M.L.H. Green, R.E. Douthwaite, L.H. Rees, Dalton (2000) 4555.

[8] G.I. Nikonov, P. Mountford, L.G. Kuzmina, J.A.K. Howard, D.A. Lemenovskii, D.M. Roitershtein, J. Organomet. Chem. 628 (2001) 25.

[9] P. Nicolás, P. Royo, M.V. Galakhov, O. Blacque, H. Jacobsen, H. Berke, Dalton Trans. (2004) 2943.

[10] T. Cuenca, P. Royo, Coord. Chem. Rev. 193-195 (1999) 447.

[11] (a) M.I. Alcalde, M.P. Gómez-Sal, P. Royo, Organometallics 20 (2001) 4623;

(b) M.I. Alcalde, M.P. Gómez-Sal, P. Royo, Organometallics 18 (1999) 546.

[12] (a) M.V. Galakhov, M. Gómez, G. Jiménez, M.A. Pellinghelli, P. Royo, A. Tiripicchio, Organometallics 13 (1994) 1564;

(b) M. Gómez, P. Gómez-Sal, M.P. Nicolás, P. Royo, J. Organomet. Chem. 491 (1995) 121;

(c) M.V. Galakhov, M. Gómez, G. Jiménez, P. Royo, Organometallics 14 (1995) 2843;

(d) M. Gómez, P. Gómez-Sal, G. Jiménez, A. Martín, P. Royo, J. Sánchez-Nieves, Organometallics 15 (1996) 3579;

(e) A. Castro, M.V. Galakhov, M. Gómez, P. Gómez-Sal, A. Martín, P. Royo, J. Organomet. Chem. 554 (1998) 185;

(f) P. Royo, J. Sánchez-Nieves, M.A. Pellinghelli, A. Tiripicchio, J. Organomet. Chem. 563 (1998) 15;

(g) P. Royo, J. Sánchez-Nieves, J. Organomet. Chem. 597 (2000) 61 ;

(h) J. Sánchez-Nieves, P. Royo, M.A. Pellinghelli, A. Tiripicchio, Organometallics 19 (2000) 3161;

(i) J. Sánchez-Nieves, P. Royo, J. Organomet. Chem 621 (2001) 299.

[13] (a) F. Amor, P. Gómez-Sal, E. de Jesús, A. Martín, Ana. I. Pérez, P. Royo, A. Vázquez de Miguel, Organometallics 15 (1996) 2103;

(b) T. Pedraz, M.A. Pellinghelli, P. Royo, A. Tiripicchio, A. Vázquez de Miguel, J. Organomet. Chem. 534 (1997) 27;

(c) P. Gómez-Sal, I. Jiménez, A. Martín, T. Pedraz, P. Royo, A. Sellés, A. Vázquez de Miguel, Inorg. Chim. Acta 273 (1998) 270; (d) F.J. de la Mata, J. Gómez, P. Royo, J. Organomet. Chem. 564 (1998) 277.

[14] A.M. Andreu, F.A. Jalón, A. Otero, P. Royo, A.M. Manotti Lanfredi, A. Tiripicchio, J. Chem. Soc., Dalton Trans. (1987) 953.

[15] M. Gómez, P. Royo, J.M. Selas, J. Organomet. Chem. 314 (1986) 131.

[16] M.J. Bunker, A. De Cian, M.L.H. Green, J. Chem. Soc., Chem. Commun. (1977) 59.

[17] J. de la Mata, R. Fandos, M. Gómez, P. Gómez-Sal, S. Martínez Carrera, P. Royo, Organometallics 9 (1990) 2846.

[18] S. Schmidt, J. Sundermeyer, J. Organomet. Chem. 472 (1994) 127.

[19] M.J. Humphries, M.L.H. Green, M.L. Leech, V.C. Gibson, M. Jolly, D.N. Williams, M.R.J. Elsegood, W. Clegg, Dalton Trans. (2000) 4044

[20] (a) M.L.H. Green, G. Hogarth, P.C. Konidaris, P. Mountford, J. Chem. Soc., Dalton Trans. (1990) 3781;

(b) J.C. Green, M.L.H. Green, J.T. James, P.C. Konidaris, G.H. Maunder, P. Mountford, J. Chem. Soc., Dalton Trans. (1992) 1361;

(c) S. Schmidt, J. Sundermeyer, J. Organomet. Chem. 472 (1994) 127 ;

(d) A. Antiñolo, P. Espinosa, M. Fajardo, P. Gómez-sal, C. 
López-Mardomingo, A. Martín-Alonso, A. Otero, J. Chem. Soc., Dalton Trans. (1995) 1007;

(e) W.A. Herrmann, W. Baratta, E. Herdtweck, Angew. Chem. Int., Ed. Eng. 35 (1996) 1951;

(f) M.L.H. Green, J.T. James, A.N. Chernega, J. Chem. Soc., Dalton Trans. (1997) 1719.

[21] R.B. King, F.G.A. Stone, W.L. Jolly, G. Austin, W. Covey, D. Ravinovich, H. Steinberg, R. Tsugawa, Inorg. Synth. 7 (1963) 99.
[22] R.B. King, F.G.A. Stone, W.L. Jolly, G. Austin, W. Covey, D. Ravinovich, H. Steinberg, R. Tsugawa, Inorg. Synth. 7 (1963) 99.

[23] M.J. Bunker, A. de Cian, M.L.H. Green, J. Chem. Soc., Chem. Commun. (1977) 59.

[24] R.B. King, F.G.A. Stone, Inorg. Synth. 7 (1963) 99.

[25] R.D. Sanner, S.T. Carter, W.J. Bruton, J. Organomet. Chem. 240 (1982) 157.

[26] P. Royo, J. Sánchez-Nieves, J. Organomet. Chem. 597 (2000) 61. 